\title{
Dimethylsulfoniopropionate (DMSP) and its relation to algal pigments in diverse waters of the Belize coastal lagoon and barrier reef system
}

\author{
William G. Sunda*, R. Wayne Litaker, D. Ransom Hardison, Patricia A. Tester
}

National Ocean Service, NOAA, 101 Pivers Island Road, Beaufort, North Carolina 28516, USA

\begin{abstract}
Dimethylsulfoniopropionate (DMSP) and algal pigments were measured in waters from a variety of sites in the Belize coastal lagoon and adjacent barrier reef system. Particulate concentrations of DMSP (DMSP $)$ and chl a varied by 2 orders of magnitude (1.1 to $130 \mathrm{nmol} \mathrm{l}^{-1}$ for DMSP and 0.040 to $2.9 \mu \mathrm{g} \mathrm{l}^{-1}$ for chl a). DMSP $\mathrm{p}$ was correlated with chl a $\left(\mathrm{r}^{2}=0.83\right)$ based on regression analysis of log-transformed data. It was even more closely correlated with peridinin $\left(r^{2}=0.92\right)$ and the photoprotective pigment diadinoxanthin $\left(\mathrm{r}^{2}=0.90\right)$, indicator pigments for dinoflagellates, a high-DMSP algal group. By contrast, $\mathrm{DMSP}_{\mathrm{P}}$ was poorly correlated with zeaxanthin $\left(\mathrm{r}^{2}=0.13\right)$, a marker for cyanobacteria which are thought to contain little or no DMSP. The highest $\mathrm{DMSP}_{\mathrm{p}}$ and chl a concentrations and highest mean DMSP $\mathrm{p}$ :chl a molar ratio $(39 \pm 12)$ were observed in a eutrophic mangrove embayment, whose phytoplankton community was dominated by dinoflagellates. Much lower chl a and $\mathrm{DMSP}_{\mathrm{P}}$ values and a somewhat lower average $\mathrm{DMSP}_{\mathrm{P}}$ :chl a molar ratio $(29 \pm 14)$ were observed at sites in the vicinity of the outer barrier reef/island system, where an estimated $64 \%$ of the chl $a$ on average occurred in cyanobacteria. In a diel study at one of these sites, the $\mathrm{DMSP}_{\mathrm{p}} / \mathrm{chl}$ a ratio increased during the day and decreased at night, a pattern that did not appear to be caused by variations in the algal community. The diel pattern instead may reflect a daytime increase in cellular DMSP concentration. Given DMSP's putative antioxidant function, the increase in $\mathrm{DMSP}_{\mathrm{P}}$ :chl $a$ ratios may represent a physiological response to help protect algal cells from increased oxidative stress during the day linked to solar UV-radiation and photosynthesis.
\end{abstract}

KEY WORDS: Dimethylsulfoniopropionate - DMSP · Phytoplankton · Dinoflagellates · Belize · Tropical Lagoon · Barrier Reef · Pigments · CHEMTAX

\section{INTRODUCTION}

Dimethylsulfoniopropionate (DMSP) is the metabolic precursor for dimethyl sulfide (DMS), a biologically produced gas that influences atmospheric acidity, cloud formation, and global climate (Charlson et al. 1987). DMSP is a low molecular mass sulfur compound $\left(\mathrm{M}_{\mathrm{r}}\right.$ 135) that occurs at high intracellular concentrations (100 to $500 \mathrm{mmol} \mathrm{l}^{-1}$ ) in many marine algal species. It occurs in appreciable concentrations only in eucaryotic algae and is either absent or present at very low levels in cyanobacteria (Keller et al. 1989, Vogt et al. 1998). Among eukaryotic algal groups, dinoflagellates, haptophytes (prymnesiophytes), chrysophytes, pelegaphytes, and prasinophytes typically contain high concentrations of DMSP, while diatoms, cryptomonads, chlorophytes, and euglenophytes often contain little or no DMSP (Keller et al. 1989). In addition, a number of environmental factors, including light intensity, solar UV radiation, and availability of limiting nutrients can influence DMSP concentrations within individual algal species (Stefels \& van Leeuwe 1998, Keller et al. 1999, Sunda et al. 2002, Bucciarelli \& Sunda 2003).

DMSP is enzymatically cleaved to dimethyl sulfide and acrylate by the enzyme DMSP lyase, which occurs in both marine algae and bacteria (Cantoni \& Anderson 1956, Ledyard \& Dacey 1994, Steinke et al. 1998). 
A portion of the released DMS diffuses into the atmosphere where it is converted by a series of oxidation steps to acidic sulfur aerosols (Andreae \& Crutzen 1997). These serve as cloud condensation nucleii, which regulate cloud formation and solar reflectance, and thus solar heating of the earth's surface (Bates et al. 1987, Charlson et al. 1987). Consequently, processes that influence DMSP production by marine algae and its enzymatic conversion to DMS may impact climate at both local and global scales.

To understand the factors that regulate DMSP production by marine algae, including those that select for high-DMSP-containing species, one must first understand the physiological functions of this molecule and its enzymatic breakdown products. DMSP is a metabolically compatible solute and serves in marine algae as an osmolyte or osmotic regulant (Reed 1983, Vairavamurthy et al. 1985). However, DMSP and its breakdown products also appear to have several other metabolic functions. These include active grazing defense due to the toxicity of acrylate (Wolfe et al. 1997) and antioxidant protection owing to the ability of DMSP, acrylate, DMS, and the oxidation product dimethyl sulfoxide to scavenge reactive oxygen species, particularly highly toxic hydroxyl radicals (Sunda et al. 2002). In support of an antioxidant function, a number of oxidative stress factors, such as solar UVradiation and limitation by nutrients $\left(\mathrm{N}, \mathrm{CO}_{2}\right.$, and $\left.\mathrm{Fe}\right)$ have been shown to increase intracellular DMSP concentrations or DMSP lysis to DMS and acrylate within individual algal species or microalgal communities (Keller et al. 1999, Sunda et al. 2002, Harada et al. 2004).

There have been numerous studies of particulate DMSP (DMSP $P_{\mathrm{P}}$ ) distributions in coastal and oceanic waters. Often $\mathrm{DMSP}_{\mathrm{P}}$ is found to be poorly correlated with chlorophyll a ( $\mathrm{chl} \mathrm{a)} \mathrm{concentrations} \mathrm{despite} \mathrm{the} \mathrm{role} \mathrm{of}$ marine algae in synthesizing both compounds (Iverson et al. 1989, Townsend \& Keller 1996, Dacey et al. 1998). More recently there have been attempts to link variations in $\mathrm{DMSP}_{\mathrm{P}}$ to marker pigments for high-DMSP algal groups. Many of these studies have shown a correlation of $\mathrm{DMSP}_{\mathrm{P}}$ with such biomarker pigments, including 19'-hexanoyloxyfucoxanthin (haptophytes) and 19'-butanoyloxyfucoxanthin (chrysophytes and pelegaphytes) (Holligan et al. 1993, Belviso et al. 2001). However, other studies have shown no clear correlations between $\mathrm{DMSP}_{\mathrm{P}}$ and biomarker pigments (Dacey et al. 1998, Harada et al. 2004). To date there have been no studies of DMSP concentrations in phytoplankton from coastal tropical environments, such as barrier reef lagoons. These environments may be of particular interest, given their clear shallow waters and consequent exposure of phytoplankton to high levels of solar radiation, a known oxidative stressor.
In the present study, we measured particulate concentrations of DMSP, chl $a$, and biomarker pigments in samples collected from shallow waters of the Belize coastal lagoon and adjacent barrier reef/island system, the largest such system in the Western Hemisphere. Samples were collected from a variety of sites encompassing a wide range of concentrations of nutrients, chl $a_{1}$ and $\mathrm{DMSP}_{\mathrm{P}}$. These sites ranged from highly productive mangrove embayments to low productivity waters in and around the outer barrier reef and adjacent islands. Pigment distributions were used to delineate the presence of various microalgal groups in an attempt to relate variations of $\mathrm{DMSP}_{\mathrm{P}}$ and $\mathrm{DMSP}_{\mathrm{P}} / \mathrm{chl} a$ ratios to differences in algal taxa. We also conducted a diel study at an oligotrophic site to investigate day/ night variations in $\mathrm{DMSP}_{\mathrm{P}}$, chl $a$, and algal pigments. This study was undertaken because of the paucity of diel data for DMSP.

\section{MATERIALS AND METHODS}

Sampling sites. Samples were collected in May 2003 from a series of sites in the Belize central lagoon and adjacent barrier reef/island system (Fig. 1). The sites ranged from small highly productive mangrove embayments within the central lagoon (Douglas Cay and the Lair at Twin Cays) to oligotrophic sites in and around the outer barrier reef system. Douglas Cay $\left(16.708^{\circ} \mathrm{N}, 88.171^{\circ} \mathrm{W}\right)$, the most heavily sampled site, is a small mangrove island $\sim 15 \mathrm{~km}$ SSW of the Smithsonian Field Station at Carrie Bow Cay (Fig. 1). The island is an overwash mangrove forest, characterized by a dense network of prop roots with no dry land (Lugo \& Snedaker 1974). The sampling station (DC-2) was located within a shallow embayment ( 2 $\mathrm{m}$ deep) at the southern end of the island, surrounded by red mangroves and enclosed by a shallow $(<1 \mathrm{~m})$ sill, which isolated the water inside.

Samples were also collected from a second mangrove embayment, the Lair, a shallow cove ( $1 \mathrm{~m}$ deep) located at Twin Cays $\left(16.829^{\circ} \mathrm{N}, 88.101^{\circ} \mathrm{W}\right)$. Twin Cays are a pair of small mangrove islands that lie approximately $3 \mathrm{~km}$ NW of Carrie Bow Cay (Fig. 1). The Lair is surrounded by mangroves and has a narrow entrance channel that limits exchange with surrounding waters.

Lower productivity sites were also sampled within the open waters of the Belize central lagoon and barrier reef system. A series of diel surface samples were collected over a $2 \mathrm{~d}$ period from the Smithsonian Field Station dock at Carrie Bow Cay $\left(16.800^{\circ} \mathrm{N}, 88.083^{\circ} \mathrm{W}\right)$, a barrier reef island adjacent to major inlets that connect the Belize central lagoon with the Caribbean Sea (Fig. 1). The sampling station was located on the west- 
ern (landward) side of the island. The sampling site had a mean water depth of $\sim 1.5 \mathrm{~m}$ and overlaid a mixed bottom of calcareous sand and sea grass Thalassia testudinium. The area around Carrie Bow Cay contains a network of coral ridges, sea grass beds and small islands colonized primarily by the red mangrove Rhizophora mangle (Macintyre et al. 2000). Single surface samples were also collected from the fore reef 200 m seaward of Carrie Bow Cay and a site on the lagoon periphery next to Tobacco Cay (Fig. 1). Two open water sites within the Belize central lagoon (Tobacco Range and Blue Ground Range) were also sampled (Fig. 1).

Physical conditions. Water temperature and salinity were measured with a YSI profiling unit (model 660). Attenuation of solar radiation was measured at the Douglas Cay embayment on a bright sunny day with an Ocean Optics USB2000 spectral radiometer fitted with a fiber optic cable. All sensors were deployed and calibrated in accordance with the instructions provided by the instrument manufacturers.

Sample collection. Surface water samples were collected with a rinsed polypropylene beaker. Samples of mid-depth and bottom water at Stn DC-2 and bottom water at the Lair were collected using a polyethylene side arm flask, a hand vacuum pump and polypropylene tubing. Samples were transferred to 31 polyethylene cubitainers, and immediately placed in the dark in a plastic cooler for transport back to the laboratory. There, 3 to $5 \mathrm{ml}$ subsamples were taken for $\mathrm{DMSP}_{\mathrm{p}}$ analysis. The remaining 2 to 31 were retained for algal pigment analysis. The elapsed time from collection to filtration of samples for particulate DMSP and algal pigments was 5 to $10 \mathrm{~min}$ for the Carrie Bow Cay dock samples, to $40 \mathrm{~min}$ to $1.5 \mathrm{~h}$ for samples collected from more remote sites such as Douglas Cay.

Particulate DMSP analysis. Particulate DMSP was measured by gas chromatography following its conversion to DMS by base hydrolysis (Kiene \& Service 1991). Briefly, a 3 to $5 \mathrm{ml}$ sub-sample was gently filtered onto a $25 \mathrm{~mm}$ GF/F filter, which was immediately placed in $3 \mathrm{ml}$ of $5 \mathrm{~N}$ $\mathrm{NaOH}$ in a $14 \mathrm{ml}$ glass septum vial to hydrolyze particulate DMSP to DMS. The vial was promptly sealed and subsequently transported back to the Beaufort Laboratory for analysis. The released DMS in the vials was measured within 8 to $11 \mathrm{~d}$ of sample collection with a Shimadzu GC 14-
A gas chromatograph fitted with a flame photometric detector and a purge and liquid nitrogen trap system. Generally, 3 sample replicates were analyzed; however, due to a shortage of sample vials, some samples collected the final $2 \mathrm{~d}$ of the sampling trip (12 and 13 May) were analyzed only singly or in duplicate. For the 16 triplicate samples, the average standard deviation was $23 \%$ of the mean. These relatively high SD values likely reflect the small sample size $(3 \mathrm{ml})$, the low algal biomass in many samples, and the presence of DMSP in large-celled algal species (e.g. dinoflagellates) or particulate cellular aggregates.

Ammonium concentrations. Surface water samples were analyzed for $\mathrm{NH}_{4}{ }^{+}$using a modification of the fluorometric method described by Holmes et al. (1999). Ammonium samples were collected at the Douglas Cay embayment site and a site in open waters of the outer lagoon near Carrie Bow Cut

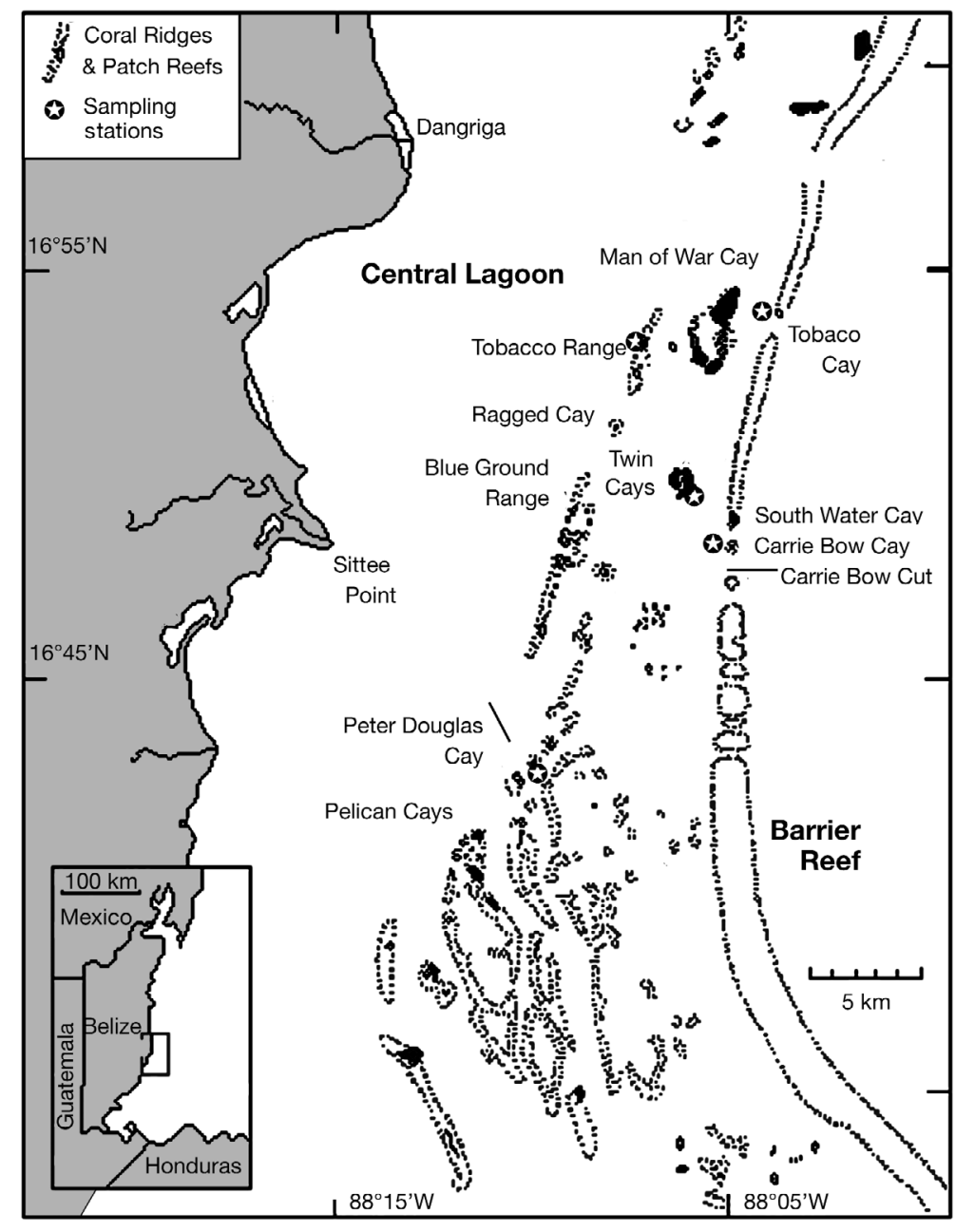

Fig. 1. Locations of the sampling stations in the central Belize lagoon; adapted from map drawn by M. Ryan, Smithsonian Institute 
(Fig. 1). The samples were collected with a pre-rinsed $60 \mathrm{ml}$ plastic syringe and dispensed in the field through $25 \mathrm{~mm}, 0.2 \mu \mathrm{m}$ pore nylon syringe filters into $15 \mathrm{ml}$ polyethylene centrifuge tubes. Each syringe was rinsed 3 times with ambient water between samples and new tubes and filters were used for each sample. Analytical reagents were added in the field and the samples were immediately transported in a plastic cooler back to the lab, where ammonium concentrations were measured with a Turner Designs fluorometer (model TD-700).

Phytoplankton pigments and taxonomic composition. Two to $3 \mathrm{l}$ water samples were filtered onto $25 \mathrm{~mm} \mathrm{GF/F}$ filters (<10 cm Hg) for HPLC analysis of algal pigments. Filters containing the retained algal pigments were folded, blotted dry and immediately frozen in liquid nitrogen for later analysis. Phytoplankton pigments were then extracted and quantified according to the methods described in Örnólfsdóttir \& Pinckney (2003). A Shimadzu HPLC fitted with single monomeric (Rainin Microsorb-MV, $0.46 \times$ $10 \mathrm{~cm}, 3 \mu \mathrm{m}$ ) and polymeric (Vydac 201TP, $0.46 \times$ $25 \mathrm{~cm}, 5 \mu \mathrm{m}) \mathrm{C} 18$ columns in series was employed to separate the extracted pigments. Absorption spectra and chromatograms $(440 \mathrm{~nm})$ were acquired using a Shimadzu photodiode array detector (model SPD-M $10 \mathrm{av})$.

Pigment concentrations were analyzed using CHEMTAX 1.0 (CHEMical TAXonomy) to estimate microalgal class abundance as described by Mackey et al. (1997). Because the phytoplankton pigments at the Douglas Cay embayment had not been previously characterized, a generic initial pigment ratio matrix provided by Mackey et al. (1997) was used in the analysis, but with modified values $\left(0.57\right.$ and $0.20 \mathrm{~g} \mathrm{~g}^{-1}$, respectively) for ratios of peridinin and diadinoxanthin to chl $a$ in dinoflagellates. These values are the average ratios measured in endosymbiotic dinoflagellates (zooxanthellae) from shallow tropical corals (Ambarsari et al. 1997). They are virtually identical to the average ratios (0.60 and $0.20 \mathrm{~g} \mathrm{~g}^{-1}$, respectively) for free-living dinoflagellates from shallow depths (0 to $25 \mathrm{~m}$ ) in the equatorial Pacific determined by CHEMTAX analysis of phytoplankton samples (Higgins \& Mackey 2000). Both sets of ratios are lower than those given by Mackey et al. (1997) for dinoflagellates (1.06 and $0.24 \mathrm{~g} \mathrm{~g}^{-1}$, respectively).

At the Douglas Cay site, the results of the CHEMTAX analysis were compared with microscopic counts of large-celled algal species $(\geq 10 \mu \mathrm{m}$ diameter). Microscopy samples were collected in $125 \mathrm{ml}$ brown polypropylene bottles and were fixed with Utermöhl's solution as described by Throndsen (1978). Samples were counted either with a Sedgewick-Rafter counting slide or a $25 \mathrm{ml}$ settling chamber.

\section{RESULTS}

The salinity and temperature of the coastal Belize samples were fairly uniform. Temperatures fluctuated from 28 to $31^{\circ} \mathrm{C}$ with a $\sim 2^{\circ} \mathrm{C}$ increase from dawn to late afternoon owing to solar heating. Salinities were $37 \pm$ 1 psu. They were lowest (36) in samples from the Carrie Bow Cay dock, and somewhat higher (37 and 38, respectively) in the mangrove embayments at Douglas Cay and Twin Cays (the Lair).

Surface ammonium concentrations varied among the sampling sites. The highest mean value (1.46 \pm $0.46 \mu \mathrm{mol} \mathrm{l}^{-1}$ ) was observed in the mangrove embayment at Douglas Cay while concentrations were much lower, and near the detection limit of the analytical method $(\sim 0.2 \mu \mathrm{M})$, at a site near the outer fringe of the central lagoon (Table 1). The high ammonium concentrations in the Douglas Cay embayment coincided with high chl a concentrations (Table 2).

The shallow waters of the Belize lagoon and barrier reef have a high transparency to solar radiation typical of most tropical reef systems. Light attenuation was measured in the shallow (2 $\mathrm{m}$ depth) Douglas Cay embayment with a spectral radiometer. The light attenuation at a wavelength of $550 \mathrm{~nm}$ (in the middle of the photosynthetically active range, 400 to $700 \mathrm{~nm}$ ) was $0.080 \mathrm{~m}^{-1}$, meaning that light at this wavelength was reduced by only $8 \%$ at a depth of $1 \mathrm{~m}$. By contrast, at a wavelength of $340 \mathrm{~nm}$ near the middle of the solar UV range (290 to $400 \mathrm{~nm}$ ), the attenuation coefficient was $2.0 \mathrm{~m}^{-1}$ (25× higher), which translates to an $86 \%$ reduction in intensity at a depth of $1 \mathrm{~m}$. Light attenuation should have been lower at the sites in and around the barrier reef/island system (e.g. the CBC dock), based on their lower chl a concentrations (see below) and presumed lower algal biomass and productivity. This prediction is confirmed by previous Secchi depth readings (Villareal 1995), which varied from $7 \mathrm{~m}$ in waters of the Belize central lagoon $1 \mathrm{~km}$ west of Twin Cays (our Lair site), to $18 \mathrm{~m}$ in oligotrophic waters of the barrier reef $\sim 600 \mathrm{~m}$ east of Carrie Bow

Table 1. Dissolved ammonium concentrations in surface samples from the Douglas Cay embayment and outer Belize lagoon near Carrie Bow Cut

\begin{tabular}{|ccc|}
\hline \multirow{2}{*}{ Date/time } & \multicolumn{2}{c|}{ Ammonium $\left(\mu\right.$ mol l l $\left.^{-1}\right)$} \\
\cline { 2 - 3 } & Dougrie Bow Cut \\
\hline 8 May/PM & 1.26 & 0.15 \\
10 May/AM & 1.26 & 0.23 \\
10 May/PM & 0.98 & 0.29 \\
12 May/AM & 1.61 & 0.25 \\
12 May/PM & 2.19 & 0.21 \\
& & \\
\hline
\end{tabular}


Table 2. Particulate DMSP and chl $a$ in water samples from the central Belize lagoon

\begin{tabular}{|c|c|c|c|c|c|c|}
\hline Location & Date/time $^{a}$ & $\begin{array}{l}\text { Depth } \\
\text { (m) }\end{array}$ & $\begin{array}{c}\mathrm{DMSP}_{\mathrm{P}} \\
\left(\mathrm{nmol} \mathrm{l}^{-1}\right)^{\mathrm{b}}\end{array}$ & $\mathrm{n}$ & $\begin{array}{l}\text { Chl a } \\
\left(\mu g l^{-1}\right)\end{array}$ & $\begin{array}{c}\mathrm{DMSP}_{\mathrm{P}} / \mathrm{chl} a^{-}\left(\mathrm{mol} \mathrm{mol}^{-1}\right)\end{array}$ \\
\hline \multirow[t]{14}{*}{ Douglas Cay } & 8-5/3:40 PM & 0 & $25.2(1.9)$ & 3 & 1.17 & 19.3 \\
\hline & 8-5/3:40 PM & 1 & $84.9(18.6)$ & 3 & 2.07 & 36.7 \\
\hline & 8-5/3:40 PM & 2 & $55.1(5.2)$ & 3 & 1.84 & 26.8 \\
\hline & 10-5/6:30 AM & 0 & $122(68.5)$ & 3 & 1.84 & 59.4 \\
\hline & 10-5/6:30 AM & 1 & $123(25.2)$ & 3 & 2.38 & 46.2 \\
\hline & 10-5/6:30 AM & 2 & $99.7(50.8)$ & 3 & 3.26 & 27.3 \\
\hline & 10-5/2:30 PM & 0 & $63.3(13.5)$ & 3 & 1.17 & 48.5 \\
\hline & 10-5/2:30 PM & 1 & $130(14)$ & 3 & 2.22 & 52.3 \\
\hline & 12-5/6:10 AM & 0 & 22.0 & 1 & 0.75 & 26.1 \\
\hline & 12-5/6:10 AM & 1 & 55.6 & 1 & 1.03 & 48.1 \\
\hline & 12-5/6:10 AM & 2 & 32.9 & 1 & 0.86 & 34.3 \\
\hline & $12-5 / 2: 30 \mathrm{PM}$ & 0 & $36.1(3.4)$ & 2 & 0.65 & 49.7 \\
\hline & 12-5/2:30 PM & 1 & $76.5(2.0)$ & 2 & 1.98 & 34.6 \\
\hline & 12-5/2:30 PM & 2 & $37.8(2.1)$ & 2 & 0.80 & 42.4 \\
\hline \multirow[t]{2}{*}{ Lair } & 8-5/6:20 AM & 0 & $3.81(0.47)$ & 3 & 0.38 & 9.0 \\
\hline & 8-5/6:20 AM & 1 & $5.77(2.09)$ & 3 & 0.89 & 5.8 \\
\hline Blue Ground Ra. & 10-5/2:15 PM & 0 & $3.32(0.14)$ & 3 & 0.503 & 5.9 \\
\hline Tobacco Range & 11-5/10:45 AM & 0 & $6.59(1.54)$ & 2 & 0.369 & 16.0 \\
\hline Tobacco Cay & 10-5/11:10 AM & 0 & $3.70(1.49)$ & 3 & 0.119 & 27.7 \\
\hline CBC Fore Reef & 10-5/11:15 AM & 0 & $5.24(1.08)$ & 3 & 0.108 & 43.5 \\
\hline \multirow[t]{11}{*}{ CBC Dock } & 11-5/2:20 PM & 0 & $2.23(0.82)$ & 3 & 0.073 & 27.2 \\
\hline & 11-5/5:45 PM & 0 & $1.77(0.28)$ & 3 & 0.068 & 23.2 \\
\hline & 11-5/8:19 PM & 0 & $1.83(0.13)$ & 3 & 0.074 & 22.2 \\
\hline & 11-5/11:20 PM & 0 & $1.20(0.03)$ & 2 & 0.045 & 23.8 \\
\hline & 12-5/2:20 AM & 0 & $1.12(0.06)$ & 2 & 0.063 & 16.0 \\
\hline & 12-5/5:20 AM & 0 & $1.28(0.03)$ & 2 & 0.108 & 10.5 \\
\hline & 12-5/8:20 AM & 0 & 3.33 & 1 & 0.129 & 23.0 \\
\hline & 12-5/11:20 AM & 0 & $4.20(0.20)$ & 2 & 0.081 & 46.3 \\
\hline & 12-5/6:20 PM & 0 & $4.28(0.26)$ & 2 & 0.069 & 55.6 \\
\hline & 13-5/6:20 AM & 0 & 2.01 & 1 & 0.085 & 21.2 \\
\hline & 13-5/2:00 PM & 0 & 1.67 & 1 & 0.037 & 39.9 \\
\hline
\end{tabular}

Cay (near our CBC and Fore Reef sites). The samples in the present study were collected during a sunny period near the end of the dry season.

Particulate DMSP (DMSP $)$ and chl a both varied by 2 orders of magnitude in the water samples (Table 2). The highest concentrations of $\operatorname{DMSP}_{\mathrm{P}}\left(22-130 \mathrm{nmol} \mathrm{l}^{-1}\right)$ and chl a (0.80-3.3 nmol $\mathrm{l}^{-1}$, equal to $\left.0.72-2.9 \mu \mathrm{g} \mathrm{l}^{-1}\right)$, were observed in samples from the Douglas Cay embayment collected at the surface, mid-depth $(1 \mathrm{~m})$ and near the bottom $(2 \mathrm{~m})$ on the afternoon of 8 May, and the morning and afternoon of 10 and 12 May. Afternoon depth profiles for $\mathrm{DMSP}_{\mathrm{P}}$ were similar on 8 May and 12 May, and values in both profiles were higher than those observed in the morning of 12 May (Fig. 2A). The highest $\mathrm{DMSP}_{\mathrm{P}}$ concentrations were observed on 10 May, but here there was no consistent trend between the morning and afternoon samples. Similar variations with respect to sampling depth, time of day, and date were observed for chl $a$, and for peridinin and the photoprotective pigment diadinoxanthin, the 2 major acces- sory pigments in dinoflagellates (Fig. 2B-D). These 2 pigments were closely correlated with one another and their molar ratios were similar to values observed previously in coral zooxanthellae, endosymbiotic dinoflagellates (Fig. 3). A CHEMTAX analysis indicated that dinoflagellates dominated the chl a pool, particularly in the mid-depth samples. According to this analysis, dinoflagellates accounted for $61 \pm 7 \%$ of the chl $a$ at mid-depth, $45 \pm 10 \%$ at the surface, and $51 \pm 12 \%$ near the bottom. A dominance of dinoflagellates at the Douglas Cay site was confirmed by microscopic cell counts of surface samples. These counts showed that dinoflagellates accounted for a majority of the large-celled (>10 $\mu \mathrm{m})$ phytoplankton.

Intermediate levels of $\operatorname{DMSP}_{\mathrm{P}}\left(3.3\right.$ to $6.6 \mathrm{nmol} \mathrm{l}^{-1}$ ) and chl a $\left(0.45\right.$ to $\left.0.80 \mu \mathrm{g} \mathrm{l}^{-1}\right)$ were observed in a second shallow mangrove embayment, the Lair, and in samples collected from 2 locations in open waters of the Belize central lagoon (Tobacco Range and Blue Ground Range) (Table 2, Fig. 4A). Based on our 

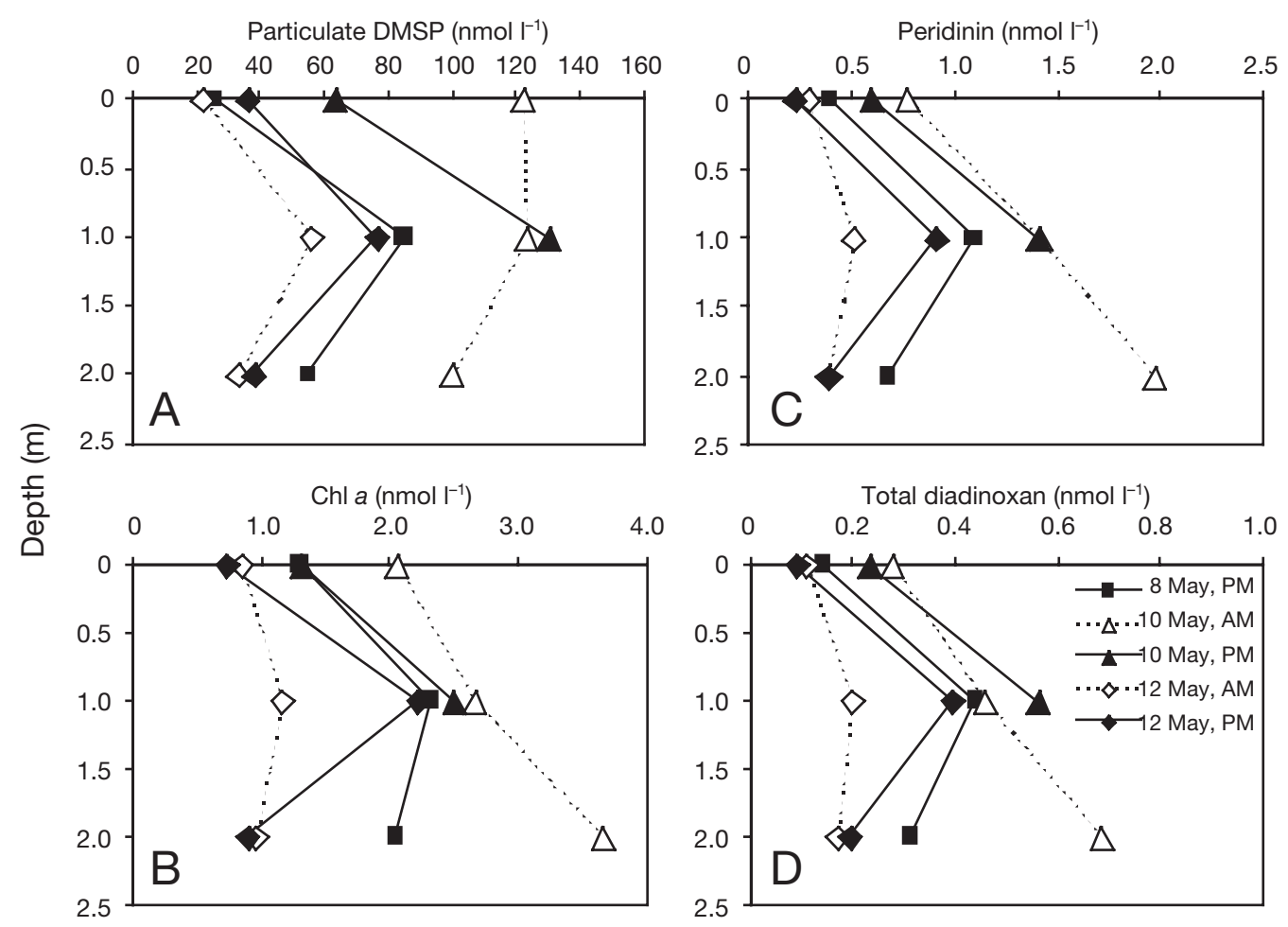

Fig. 2. Depth distributions for (A) particulate DMSP, (B) chl $a_{1}(\mathrm{C})$ peridinin, and (D) total diadinoxanthin

CHEMTAX analysis, these samples contained diverse microalgal assemblages with cyanobacteria as the dominant group, followed by roughly equal abundances of dinoflagellates and diatoms (Table 3).

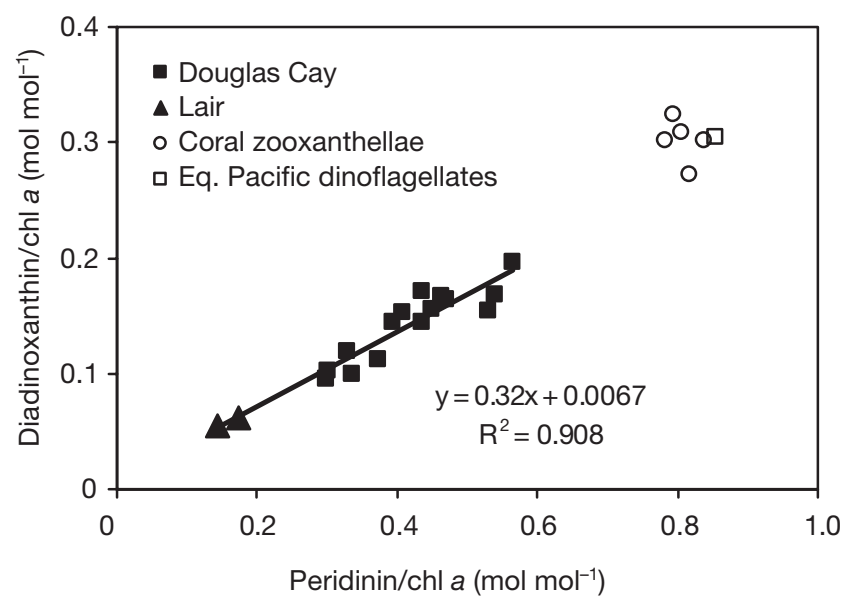

Fig. 3. Linear relationship between the molar ratio of diadinoxanthin:chl $a$ and that of peridinin:chl $a$ in the mangrove embayments at Douglas Cay and Twin Cays (the Lair). These data fall in line with those for endosymbiotic dinoflagellates, zooxanthellae, in tropical corals in Thailand (Ambarsari et al. 1997) and average values for shallow dwelling planktonic dinoflagellates in the equatorial Pacific (Higgins \& Mackey 2000) estimated from CHEMTAX pigment analysis
The lowest concentrations of $\operatorname{DMSP}_{\mathrm{P}}(1.1$ to $5.2 \mathrm{nM})$ and chl a $\left(0.04\right.$ to $\left.0.115 \mu \mathrm{g} \mathrm{l}^{-1}\right)$ were found in surface samples collected in the vicinity of the Belize barrier reef/island system (Table 2). Two of the samples were collected from waters next to Tobacco Cay and the fore reef $200 \mathrm{~m}$ seaward of Carrie Bow Cay. The rest (11 samples) were collected off the Smithsonian Field Station dock on Carrie Bow Cay (CBC). The CBC dock samples were collected at different times of day over a $48 \mathrm{~h}$ period beginning in the afternoon of 11 May. $\mathrm{DMSP}_{\mathrm{P}}$ concentrations varied between 1 and $4 \mathrm{nmol}^{-1}$ and were lower at dawn than at dusk (Fig. 5). Concentrations of chl a and the 2 dominant carotenoid pigments, zeaxanthin and fucoxanthin, also varied over the sampling period, but they showed no apparent diel pattern. Instead, the pigments appeared to be approximately in phase with the tidal cycle, with increasing concentrations during rising tides (Fig. 5). By contrast, $\mathrm{DMSP}_{\mathrm{P}}$ :chl a ratios showed a clear diel pattern, with increasing values during the day and decreasing values at night (Fig. 6).

A CHEMTAX analysis (Table 3) indicated that the algal assemblage in the $\mathrm{CBC}$ dock samples was dominated by cyanobacteria $(66 \pm 11 \%$ of the $\mathrm{chl} a)$, and to a lesser extent by diatoms $(25 \pm 6 \%$ of $\mathrm{chl} a)$ (Table 3). There was an overall low abundance of dinoflagellates, as indicated by the low concentrations of 


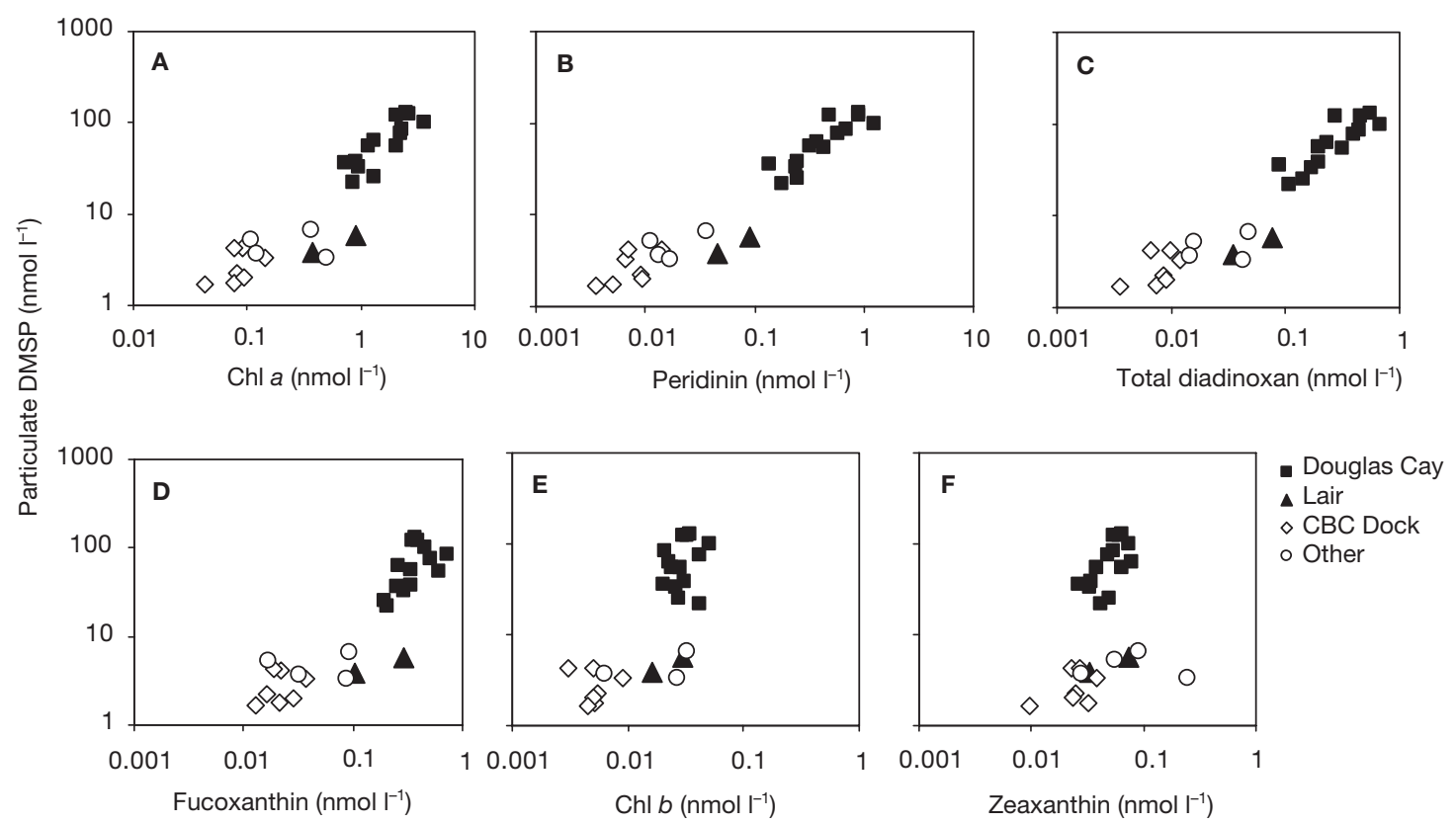

Fig. 4. Scatter plots for particulate DMSP versus chl $a$, peridinin, total diadinoxanthin, fucoxanthin, chl $b$, and zeaxanthin. Data are plotted for the Douglas Cay embayment, the Lair at Twin Cays, the Carrie Bow Cay (CBC) dock, and 4 other samples from Blue Grass Range, Tobacco Range, Tobacco Cay, and the fore reef off-shore of Carrie Bow Cay. To be comparable with other samples from other sites, only daytime values are plotted for the Carrie Bow Cay dock samples

the biomarker pigment peridinin. Other high DMSP algal groups, including haptophytes, chrysophytes, and prasinophytes, showed even lower abundances (Table 3). Similar distributions were observed in the $\mathrm{CBC}$ fore reef sample. In this sample cyanobacteria, dinoflagellates and diatoms accounted for an estimated 68,18 , and $8 \%$, respectively, of the chl $a$ (Table 3).

Scatter plots (Fig. 4) and linear regressions of logtransformed data (Table 4) show a close correlation between particulate concentrations of DMSP and those of some algal pigments. A linear regression of log $\mathrm{DMSP}_{\mathrm{P}}$ versus log chl a for all daytime samples yielded an $\mathrm{r}^{2}$ of 0.83 and a slope of 1.02 (Table 4). The unity slope indicates an approximate proportionality between the 2 parameters and shows that ratios of $\mathrm{DMSP}_{\mathrm{P}} / \mathrm{chl}$ a do not vary appreciably with chl a concentration. The mean $\mathrm{DMSP}_{\mathrm{P}}$ :chl a molar ratio for all daytime samples was $41 \pm 19$, consistent with overall high DMSP concentrations in the phytoplankton. Biomarker pigments for dinoflagellates (peridinin and diadinoxanthin), a high DMSP algal group, showed even higher correlations with $\mathrm{DMSP}_{\mathrm{P}}$ (Table 4). By contrast, log $\mathrm{DMSP}_{\mathrm{P}}$ was poorly correlated with log zeaxanthin $\left(\mathrm{r}^{2}=0.13\right)$. Zeaxanthin is the main biomarker pigment for cyanobacteria, an algal group thought to contain little or no DMSP (Keller et al. 1989). Intermediate regression $\mathrm{r}^{2}$ values were observed for fucoxanthin (0.80), a biomarker for diatoms, and chl $b$ (0.55), an accessory pigment in chlorophytes, euglenophytes, and prasinophytes. The latter 3 eucaryotic algal groups are observed to contain little or no DMSP, while diatoms generally contain low, variable amounts that often increase substantially under nutrient limitation (Keller et al. 1989, Bucciarelli \& Sunda 2003).

\section{DISCUSSION}

We observed a 2 order of magnitude range in $\mathrm{DMSP}_{\mathrm{P}}$ concentrations in water samples from the Belize lagoon/barrier reef system. Despite this wide range, however, average daytime $\mathrm{DMSP}_{\mathrm{P}}$ :chl a ratios were similar among the sampling sites. At the 2 most highly sampled sites, the high ammonium and high chl a mangrove embayment at Douglas Cay and the oligotrophic waters off the Carrie Bow Cay dock, the average daytime DMSP $_{\mathrm{P}}$ :chl a molar ratios were $39 \pm$ 12 and $34 \pm 14$, respectively. If we include the nighttime samples from the CBC dock, the overall average ratio at this site was somewhat lower $(28 \pm 14)$. The pattern between the 2 sites contrasts the situation in temperate and subtropical waters of the NE Atlantic and Gulf or Mexico, where high-chlorophyll estuarine and coastal waters have DMSP $_{\mathrm{P}}$ :chl a ratios that are an order of magnitude lower than those (60 to $200 \mathrm{~mol}$ 
Table 3. Percentage of chl a in different microalgal taxa based on CHEMTAX analysis of algal pigments. The algal taxa abbreviations are for dinoflagellates, diatoms, chlorophytes, cryptophytes, chrysophytes, haptophytes, euglenophytes, prasinophytes, and cyanobacteria, respectively

\begin{tabular}{|c|c|c|c|c|c|c|c|c|c|c|c|}
\hline Location & Date/time & Depth (m) & Dino & Diat & Chlor & Cryp & Chrys & Hapt & Eugl & Pras & Cyano \\
\hline \multirow[t]{14}{*}{ Douglas Cay } & 8-5/3:40 PM & 0 & 43.0 & 11.2 & 3.8 & 4.6 & 5.0 & 0.6 & 1.9 & 1.1 & 28.8 \\
\hline & 8-5/3:40 PM & 1 & 55.4 & 22.3 & 4.7 & 8.1 & 5.3 & 0.8 & 0.0 & 0.0 & 3.3 \\
\hline & 8-5/3:40 PM & 2 & 43.5 & 22.5 & 6.2 & 10.0 & 6.2 & 1.3 & 0.0 & 0.0 & 10.2 \\
\hline & $10-5 / 6: 30 \mathrm{AM}$ & 0 & 50.5 & 12.5 & 2.4 & 8.2 & 6.3 & 0.4 & 0.2 & 1.1 & 18.5 \\
\hline & $10-5 / 6: 30 \mathrm{AM}$ & 1 & 66.6 & 6.0 & 4.6 & 7.8 & 5.9 & 0.3 & 0.0 & 0.2 & 8.6 \\
\hline & $10-5 / 6: 30 \mathrm{AM}$ & 2 & 68.5 & 1.7 & 5.0 & 8.4 & 8.6 & 0.4 & 0.0 & 0.4 & 7.0 \\
\hline & 10-5/2:30 PM & 0 & 59.1 & 13.8 & 4.7 & 7.7 & 4.8 & 0.5 & 0.0 & 0.7 & 8.6 \\
\hline & 10-5/2:30 PM & 1 & 68.9 & 5.5 & 5.0 & 9.5 & 6.1 & 0.5 & 0.0 & 0.2 & 4.2 \\
\hline & $12-5 / 6: 10 \mathrm{AM}$ & 0 & 39.0 & 14.7 & 4.4 & 6.3 & 7.5 & 0.8 & 5.4 & 2.3 & 19.6 \\
\hline & $12-5 / 6: 10 \mathrm{AM}$ & 1 & 55.8 & 18.9 & 4.5 & 4.4 & 8.2 & 0.6 & 0.7 & 1.6 & 5.2 \\
\hline & $12-5 / 6: 10 \mathrm{AM}$ & 2 & 49.3 & 25.8 & 1.2 & 10.5 & 3.3 & 0.0 & 3.0 & 1.0 & 5.9 \\
\hline & 12-5/2:30 PM & 0 & 34.3 & 29.7 & 2.8 & 13.6 & 4.1 & 0.0 & 3.3 & 1.0 & 11.1 \\
\hline & 12-5/2:30 PM & 1 & 56.2 & 15.8 & 5.3 & 11.6 & 5.8 & 0.6 & 0.0 & 0.9 & 3.8 \\
\hline & 12-5/2:30 PM & 2 & 43.6 & 28.1 & 4.4 & 9.6 & 3.3 & 0.7 & 4.1 & 0.8 & 5.5 \\
\hline \multirow[t]{2}{*}{ Lair } & 8-5/6:20 AM & 0 & 25.9 & 16.7 & 4.6 & 12.4 & 7.6 & 3.3 & 1.5 & 1.0 & 27.0 \\
\hline & 8-5/6:20 AM & 1 & 18.8 & 26.2 & 5.5 & 15.7 & 3.2 & 1.4 & 0.5 & 2.0 & 26.7 \\
\hline Blue Ground Ra. & 10-5/2:15 PM & 0 & 5.3 & 8.1 & 2.6 & 0.0 & 5.6 & 0.0 & 7.5 & 0.4 & 70.6 \\
\hline Tobacco Range & $11-5 / 10: 45$ AM & 0 & 11.0 & 12.4 & 0.2 & 12.2 & 7.4 & 3.3 & 18.6 & 0.7 & 34.3 \\
\hline Tobacco Cay & 10-5/11:10 AM & 0 & 10.2 & 21.1 & 0.0 & 0.0 & 0.1 & 5.0 & 21.2 & 0.0 & 42.4 \\
\hline Fore Reef & 10-5/11:15 AM & 0 & 18.0 & 8.1 & 0.0 & 0.0 & 0.3 & 5.4 & 0.3 & 0.0 & 67.9 \\
\hline \multirow[t]{11}{*}{ CBC Dock } & 11-5/2:20 PM & 0 & 16.1 & 19.6 & 0.2 & 0.3 & 0.0 & 0.0 & 0.0 & 0.0 & 63.7 \\
\hline & $11-5 / 5: 45$ PM & 0 & 0.0 & 19.4 & 0.1 & 0.1 & 0.0 & 0.0 & 0.0 & 0.0 & 80.4 \\
\hline & 11-5/8:19 PM & 0 & 0.0 & 32.1 & 0.0 & 0.0 & 0.0 & 0.0 & 0.0 & 0.0 & 67.9 \\
\hline & $11-5 / 11: 20 \mathrm{PM}$ & 0 & 0.5 & 27.7 & 0.1 & 0.2 & 0.0 & 0.0 & 0.0 & 0.0 & 71.4 \\
\hline & $12-5 / 2: 20 \mathrm{AM}$ & 0 & 1.9 & 23.9 & 0.2 & 0.3 & 0.0 & 0.0 & 0.0 & 0.0 & 73.7 \\
\hline & $12-5 / 5: 20 \mathrm{AM}$ & 0 & 0.0 & 25.4 & 1.2 & 0.1 & 0.0 & 0.0 & 17.4 & 2.0 & 53.9 \\
\hline & $12-5 / 8: 20 \mathrm{AM}$ & 0 & 7.1 & 22.8 & 0.0 & 0.0 & 0.1 & 5.0 & 21.4 & 0.0 & 43.5 \\
\hline & $12-5 / 11: 20 \mathrm{AM}$ & 0 & 2.8 & 21.0 & 0.3 & 0.4 & 0.0 & 0.0 & 0.0 & 0.0 & 75.4 \\
\hline & $12-5 / 6: 20 \mathrm{PM}$ & 0 & 12.8 & 18.1 & 0.0 & 0.0 & 0.0 & 0.0 & 0.0 & 0.0 & 69.1 \\
\hline & $13-5 / 6: 20 \mathrm{AM}$ & 0 & 12.8 & 33.4 & 0.2 & 0.3 & 0.0 & 0.0 & 0.0 & 0.0 & 53.4 \\
\hline & 13-5/2:00 PM & 0 & 0.0 & 33.5 & 0.0 & 0.0 & 0.0 & 0.0 & 0.0 & 0.0 & 66.4 \\
\hline
\end{tabular}

$\mathrm{mol}^{-1}$ ) typically found in oligotrophic offshore waters (Iverson et al. 1989, Kiene \& Linn 2000, Harada et al. 2004).

The CHEMTAX pigment analysis and microscopic cell counts indicate that the high $\mathrm{DMSP}_{\mathrm{p}}$ :chl $a$ values at the Douglas Cay sampling site are related to a high abundance of dinoflagellates, both in terms of overall biomass and proportion of the chl a pool. Based on the CHEMTAX analysis, the highest proportion of dinoflagellates ( $61 \pm 7 \%$ of the chl a pool) occurred at middepth $(\sim 1 \mathrm{~m})$ where the mean $\mathrm{DMSP}_{\mathrm{p}}$ :chl a ratio $(44 \pm$ 8) was also high. If we assume that all of the $\mathrm{DMSP}_{\mathrm{p}}$ is contained in dinoflagellates in the mid-depth samples, then the mean DMSP:chl a molar ratio for these dinoflagellates would be 72 , similar to the value $(89 \pm$ 14) we measured at saturating light (500 $\mu \mathrm{mol}$ quanta $\mathrm{m}^{2} \mathrm{~s}^{-1}$ of PAR) in nutrient sufficient cultures of Amphidinium carterae (W. G. Sunda, D. R. Hardison, R. P. Kiene unpubl. data), a high-DMSP dinoflagellate. Somewhat lower DMSP:chl a molar ratios of 55 (Keller et al. 1999) and 38 (Keller \& Korjeff-Bellows 1996) have been measured in nutrient-sufficient cultures of this species at 2- and 3-fold lower light intensities (250 and $166 \mu \mathrm{mol}$ quanta $\mathrm{m}^{2} \mathrm{~s}^{-1}$, respectively). The decrease in DMSP:chl a ratios with decreasing light intensity may be linked to low-light photoacclimation, which increases cellular chl a concentrations. In the low-light study of Keller \& Korjeff-Bellows (1996), 3 other dinoflagellates (Prorocentrum minimum, P. micans, and Gymnodinium simplex) had DMSP:chl a molar ratios of 37,33, and 124, similar to the value measured in A. carterae (38). In the Douglas Cay embayment, other high-DMSP algal groups (chrysophytes, prasinophytes, and haptophytes) contributed only an estimated $5.8 \pm 0.3,0.8 \pm 0.6$, and $0.5 \pm 0.3 \%$ to the particulate chl a pool, and thus are unlikely to be significant contributors of particulate DMSP.

The tendency of phototrophic dinoflagellates to accumulate at mid-depth $(1 \mathrm{~m})$ in the Douglas Cay embayment may be linked to their well-known phototaxis and associated vertical migration patterns. Dinoflagellates may preferentially reside at mid- 


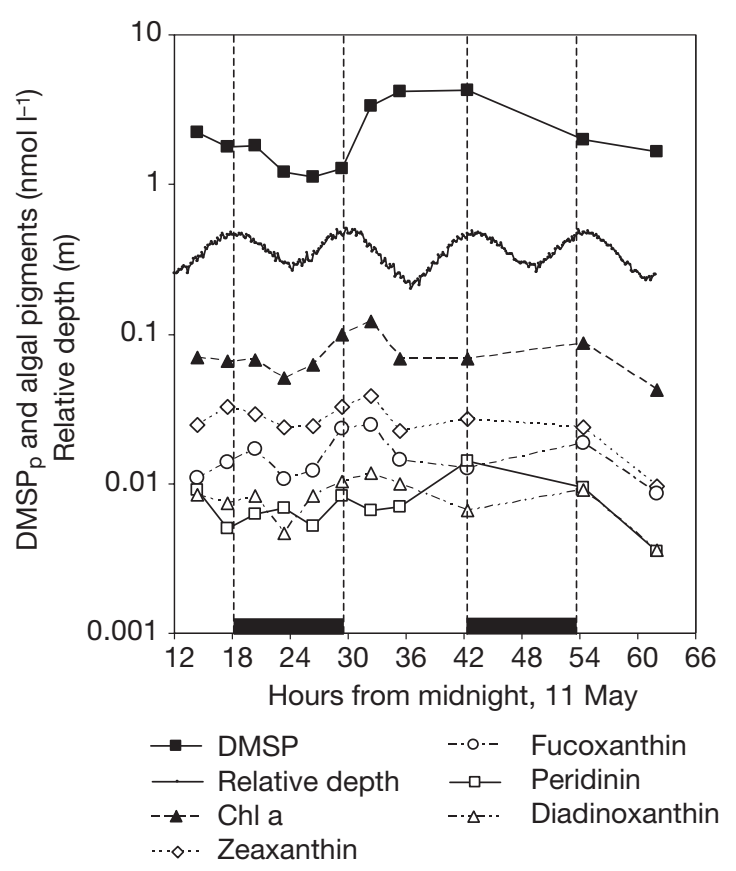

Fig. 5. Diel variations in $\operatorname{DMSP}_{\mathrm{P}_{1}}$ chl $a_{\text {, }}$ and biomarker pigments in surface water sampled off the Carrie Bow Cay dock over a $2 \mathrm{~d}$ period. Relative depth was measured from a tide meter positioned $1.2 \mathrm{~m}$ above the bottom. The mean water depth at this site is $\sim 1.5 \mathrm{~m}$. Nighttime is indicated by dark rectangles on the $x$-axis

depths during the day to optimize their light exposure, and may tend to avoid the surface to minimize exposure to harmful levels of solar UV-radiation. Their motility and positive phototatic behavior exposes these organisms to potentially harmful levels of solar radiation, and consequently dinoflagellates have had to evolve mechanisms to protect themselves from such

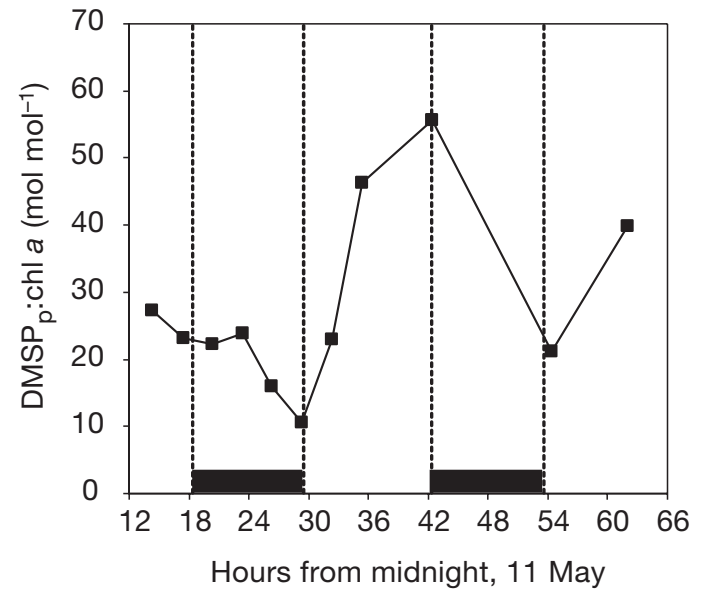

Fig. 6. Diel variations in the molar ratio of $\mathrm{DMSP}_{\mathrm{p}}$ :chl $a$ in surface water sampled off the Carrie Bow Cay dock. Nighttime is indicated by the dark rectangles on the $x$-axis

harm. Phototrophic dinoflagellates typically contain high levels of photoprotective pigments, including UVscreening compounds and diadinoxanthin (Vernet et al. 1989, Higgins \& Mackey 2000, also see Fig. 3). The latter pigment protects chl $a$ and other light harvesting pigments from overexcitation at high light intensities through its enzymatic conversion to diatoxanthin. High intracellular concentrations of DMSP, a putative antioxidant (Sunda et al. 2002), may also help protect dinoflagellates from oxidative stress, a principal cause of cell damage during high exposure to solar radiation. Thus, although one may attribute the high DMSP:chl a ratios in the eutrophic Douglas Cay embayment to the presence of dinoflagellates, the fundamental cause may be the shallow clear waters and resultant high solar stress, which tends to select for dinoflagellates

Table 4. Coefficients of determination $\left(\mathrm{r}^{2}\right)$ and slopes for linear regressions of $\mathrm{DMSP}_{\mathrm{P}}$ versus algal pigment concentration based on log-transformed data

\begin{tabular}{|c|c|c|c|c|c|c|c|c|c|c|c|c|}
\hline & \multicolumn{2}{|c|}{ Chl a } & \multicolumn{2}{|c|}{ Peridinin } & \multicolumn{2}{|c|}{ Fucoxanthin } & \multicolumn{2}{|c|}{$\begin{array}{c}\text { Total dia- } \\
\text { dinoxanthin }\end{array}$} & \multicolumn{2}{|c|}{ Zeaxanthin } & \multicolumn{2}{|c|}{ Chl $b$} \\
\hline & $\begin{array}{l}\mathrm{r}^{2} \\
(\mathrm{p})\end{array}$ & Slope & $\begin{array}{l}\mathrm{r}^{2} \\
(\mathrm{p})\end{array}$ & Slope & $\begin{array}{l}r^{2} \\
(p)\end{array}$ & Slope & $\begin{array}{l}\mathrm{r}^{2} \\
(\mathrm{p})\end{array}$ & Slope & $\begin{array}{l}\mathrm{r}^{2} \\
(\mathrm{p})\end{array}$ & Slope & $\begin{array}{l}\mathrm{r}^{2} \\
(\mathrm{p})\end{array}$ & Slope \\
\hline All daytime samples ${ }^{\mathrm{b}}$ & $\begin{array}{c}0.83 \\
(<0.001)\end{array}$ & 1.02 & $\begin{array}{c}0.92 \\
(<0.001)\end{array}$ & 0.72 & $\begin{array}{c}0.80 \\
(<0.001)\end{array}$ & 1.04 & $\begin{array}{c}0.90 \\
(<0.001)\end{array}$ & 0.90 & $\begin{array}{c}0.13 \\
(0.07)\end{array}$ & 0.91 & $\begin{array}{c}0.59 \\
(<0.001)\end{array}$ & 1.42 \\
\hline Mangrove embayments & $\begin{array}{c}0.68 \\
(<0.001)\end{array}$ & 1.46 & $\begin{array}{c}0.87 \\
(<0.001)\end{array}$ & 1.09 & $\begin{array}{c}0.51 \\
(0.002)\end{array}$ & 1.57 & $\begin{array}{c}0.83 \\
(<0.001)\end{array}$ & 1.17 & $\begin{array}{c}0.11 \\
(0.22)\end{array}$ & 1.00 & $\begin{array}{c}0.17 \\
(0.12)\end{array}$ & 1.44 \\
\hline $\begin{array}{l}\text { Open lagoon and } \\
\text { lagoon periphery }\end{array}$ & $\begin{array}{c}0.33 \\
(0.07)\end{array}$ & 0.34 & $\begin{array}{c}0.59 \\
(0.006)\end{array}$ & 0.43 & $\begin{array}{c}0.21 \\
(0.16)\end{array}$ & 0.32 & $\begin{array}{c}0.44 \\
(0.03)\end{array}$ & 0.39 & $\begin{array}{c}0.26 \\
(0.11)\end{array}$ & 0.27 & $\begin{array}{c}0.07 \\
(0.46)\end{array}$ & 0.14 \\
\hline
\end{tabular}


and other organisms capable of dealing with that stress.

Overall our data show a high correlation between $\mathrm{DMSP}_{\mathrm{P}}$ and peridinin, consistent with dinoflagellates being important contributors to the particulate DMSP pool. However, chemotaxonomic surveys by Belviso et al. (2001) and Harada et al. (2004) have shown poor correlations between $\mathrm{DMSP}_{\mathrm{P}}$ and peridinin, suggesting that dinoflagellates were not important contributors in their studies. But in a study in the Gulf of Maine, Townsend \& Keller (1996) found high DMSP ${ }_{P}$ concentrations in surface samples taken during dinoflagellate blooms.

The low mean daytime $\operatorname{DMSP}_{\mathrm{p}}$ :chl a ratio at the oligotrophic $\mathrm{CBC}$ dock site was surprising given the tendency of low chl $a$ waters to have high DMSP $:$ chl $a$ ratios (Iverson et al. 1989, Dacey et al. 1998). However, results of the CHEMTAX analysis indicate that cyanobacteria, which are thought to contain little or no DMSP, constitute $64 \pm 12 \%$ of the total chl $a$ in the daytime CBC dock samples and $64 \pm 11 \%$ in all samples from this site. Thus, the unexpectedly low DMSP $\mathrm{p}$ :chl $a$ ratio at this site may be caused by the high abundance of cyanobacteria. A microscopic examination of nettow plankton samples from this site showed an abundance of the Trichodesmium, a well-documented nitrogen-fixing genus in nitrogen-limited Caribbean waters adjacent to Carrie Bow Cay (Villareal 1995). If we take the mean daytime molar ratio for $\mathrm{DMSP}_{\mathrm{P}}$ :chl a (34) and divide it by the estimated fraction of eucaryotic algal chl a (0.36), we compute a ratio of $\mathrm{DMSP}_{\mathrm{p}}$ :chl $a$ in the eucaryotic algae of 94 , consistent with values typically observed in oligotrophic open ocean environments or in cultures of high-DMSP algal species. For example, a mean DMSP: $\mathrm{phl}$ a molar ratio of $\sim 110$ was reported for stratified surface waters of the Sargasso Sea (Iverson et al. 1989) and ratios of 89 and 176 were observed in Nsufficient and N-limited cultures of the dinoflagellate Amphidinium carterae under saturating light conditions (W. G. Sunda, D. R. Hardison, and R. P. Kiene unpubl. data).

From the CHEMTAX analysis we estimate that only an average of $27 \%$ of the eucaryotic algal chl $a$ in the daytime CBC dock samples occurs in known highDMSP algal groups and that the majority of this $(77 \%)$ occurs in dinoflagellates. The remaining eucaryotic algal chl $a$ is found in low-DMSP algal groups, particularly in diatoms which account for an estimated average of $24 \%$ of the total chl $a$ and $67 \%$ of that in eucaryotic algae. However, 1 diatom species, Melosira nummuloides, is reported to contain a constitutively high intracellular DMSP concentration $\left(260 \mathrm{mmol} \mathrm{l}^{-1}\right.$; Keller et al. 1989) while others such as Thalassiosira pseudonana increase their intracellular DMSP by up to 50 -fold and their DMSP/chl a ratios by 100 -fold under nitrogen limitation (Keller et al. 1999, Bucciarelli \& Sunda 2003). Thus, much of the $\mathrm{DMSP}_{\mathrm{P}}$ may be present in diatoms, although we cannot discount the potential importance of dinoflagellates, despite their apparent low abundance. The mean $\mathrm{DMSP}_{\mathrm{p}}$ :peridinin molar ratio for the daytime CBC dock samples is $385 \pm$ 143 , which translates to a ratio of $\mathrm{DMSP}_{\mathrm{p}}$ to dinoflagellate chl $a$ of $308 \pm 114$, assuming a peridinin:chl a molar ratio of 0.8 (see Fig. 3). This is not an unreasonable ratio for severely $\mathrm{N}$-limited dinoflagellates, whose intracellular DMSP may be elevated and chl a depressed based on laboratory culture studies (Keller et al. 1999). Interestingly, similar computations for the 4 nighttime CBC dock samples yielded a mean ratio of $\mathrm{DMSP}_{\mathrm{P}}$ to dinoflagellate chl $a$ of $167 \pm 49$, which is in line with what we might expect for N-limited dinoflagellates as discussed above.

DMSP $_{\mathrm{p}}$ :chl a ratios in the CBC dock samples decreased at night and increased during the day. Similar diel patterns have been observed in surface waters of the NW Mediterranean Sea (Belviso et al. 2000). In Barcelona Harbor, DMSP $\mathrm{p}$ chl a ratios in particles $\geq 10 \mu \mathrm{m}$ diameter increased by 2 -fold between dawn and dusk, apparently linked to vertical movements of dinoflagellates, which migrate to near the surface during the day and retreat to the sediments at night. Similar variations in total particulate DMSP:chl $a$ were observed in 2 diel surveys of offshore waters (Belviso et al. 2000). But in the offshore waters there was no clear linkage with vertical migration of dinoflagellates because particulate concentrations of DMSP and the biomarker pigment peridinin each showed different depth-dependent diurnal patterns.

In the present diel study off the CBC dock, there is also no clear coherence between diel variations in $\mathrm{DMSP}_{\mathrm{P}}$ and that of peridinin, suggesting that here as in the latter example above, the increase in $\mathrm{DMSP}_{\mathrm{P}}$ during the day is not mainly caused by vertical migration of dinoflagellates. Furthermore, the mean $\mathrm{DMSP}_{\mathrm{P}}$ :peridinin ratio at the CBC dock site is higher during the day than at night, the opposite of the pattern that would occur if the daily pattern in DMSP $_{\mathrm{p}}$ :chl $a$ was linked solely to diel migration of dinoflagellates. The daytime increase in $\mathrm{DMSP}_{\mathrm{p}}$ :chl $a$ ratios may instead represent a physiological increase in intracellular DMSP in response to oxidative stress, which is directly linked to solar radiation through photosynthetic imbalances (Niogi 1999) and to the damaging effects of solar UV-radiation (Lesser \& Schick 1989). Protection from oxidative stress during the day may be particularly important in the shallow, highly transparent waters, of the Belize lagoon where a combination of high exposure to solar radiation and low nutrient availability is likely to cause a high level of such stress. 
Acknowledgements. We are grateful to M. Faust, K. Rützler, and M. Carpenter for the use of the Carrie Bow Cay field station and for their helpful support; to S. Kibler, M. Vandersea, S. Varnam, and B. Pfieffer for their assistance with field work; to J. Pinckney for HPLC analyses; and to E. Örnólfsdóttir for help with CHEMTAX analysis of algal taxonomy. This research was partially supported by a grant from the Smithsonian Institution; it is contribution number 711 of their Caribbean Coral Reef Ecosystem Program.

\section{LITERATURE CITED}

Ambarsari I, Brown BE, Barlow RG, Britton G, Cummings D (1997) Fluctuations in algal chlorophyll and carotenoid pigments during solar bleaching in the coral Goniastrea aspera at Phuket, Thailand. Mar Ecol Prog Ser 159: 303-307

Andreae MO, Crutzen PJ (1997) Atmospheric aerosols: biogeochemical sources and role in atmospheric chemistry. Science 276:1052-1058

Bates TS, Charlson RJ, Gammon RH (1987) Evidence for the climatic role of marine biogenic sulphur. Nature 329: 319-321

Belviso S, Christaki U, Vidussi F, Marty JC, Vila M, Delgado M (2000) Diel variations of the DMSP-to-chlorophyll a ratio in Northwestern Mediterranean surface waters. J Mar Syst 25:119-128

Belviso S, Claustre H, Marty JC (2001) Evaluation of the utility of chemotaxonomic pigments as a surrogate for particulate DMSP. Limnol Oceanogr 46:989-995

Bucciarelli E, Sunda WG (2003) Influence of $\mathrm{CO}_{2}$, nitrate, phosphate, and silicate limitation on intracellular DMSP in the coastal diatom Thalassiosira pseudonana. Limnol Oceanogr 48:2256-2265

Cantoni GL, Anderson DG (1956) Enzymatic cleavage of dimethylpropiothetin by Polysiphonia lanosa. J Biol Chem 22:171-177

Charlson RJ, Lovelock JE, Andreae MO, Warren SG (1987) Oceanic phytoplankton, atmospheric sulfur, cloud albedo, and climate. Nature 326:655-661

Dacey JWH, Howse FA, Michaels AF, Wakeham, SG (1998) Temporal variability of dimethylsulfide and dimethylsulfoniopropionate in the Sargasso Sea. Deep-Sea Res 45: 2085-2104

Harada H, Rouse M, Sunda W, Kiene RP (2004) Latitudinal and vertical distributions of particle-associated DMSP lyase activity in the western North Atlantic Ocean. Can J Fish Aquat Sci 61:700-711

Higgins HW, Mackey, DJ (2000) Algal class abundances, estimated from chlorophyll and carotenoid pigments, in the western Equatorial Pacific under El Niño conditions. Deep-Sea Res I 47:1461-1483

Holligan PM, Fernandez E, Aiken J, Balsh WM and 11 others (1993) A biogeochemical study of the coccolithophore, Emiliania huxleyi, in the north Atlantic. Global Biogeochem Cycles 7:879-900

Holmes RM, Aminot A, Kerouel R, Hooker BA, Peterson BJ (1999) A simple and precise method for measuring ammonium in marine and freshwater ecosystems. Can J Fish Aquat Sci 56:1801-1808

Iverson RL, Nearhoof FL, Andreae MO (1989) Production of diemthylsulfonium propionate and dimethylsulfide by phytoplankton in estuarine and coastal waters. Limnol Oceanogr 34:53-67

Keller MD, Korjeff-Bellows W (1996) Physiological aspects of the production of dimethyl sulfoniopropionate (DMSP) by marine phytoplankton. In: Kiene RP, Visscher PT, Keller MD, Kirst GO (eds) Biological and environmental chemistry of DMSP and related sulfonium compounds. Plenum Press, New York, p 131-142

Keller MD, Bellows WK, Guillard RRL (1989) Dimethyl sulfide production in marine phytoplankton. In: Saltzman ES, Cooper WJ (eds) Biogenic sulfur in the environment. ACS Symposium Series 393. American Chemical Society, Washington, DC, p 167-182

Keller MD, Kiene RP, Matrai PA, Bellows WK (1999) Production of glycine betaine and dimethylsulfoniopropionate in marine phytoplankton. II. N limited chemostat cultures. Mar Biol 135:249-257

Kiene RP, Linn LJ (2000) The fate of dissolved dimethylsulfoniopropionate (DMSP) in seawater: tracer studies using ${ }^{35}$ S-DMSP. Geochim Cosmochim Acta 64:2797-2810

Kiene RP, Service SK (1991) Decomposition of dissolved DMSP and DMS in estuarine waters: dependence on temperature and substrate concentration. Mar Ecol Prog Ser 76:1-11

Ledyard KM, Dacey JWH (1994) Dimethylsulfide production from dimethylsulfoniopropionate by a marine bacterium. Mar Ecol Prog Ser 110:95-103

Lesser MP, Shick JM (1989) Effects of irradiance and ultraviolet radiation on photo-adaptation in the zooxanthellae of Aiptasia pallida: primary production, photoinhibition, and enzymatic defenses against oxygen toxicity. Mar Biol 102:243-255

Lugo AE, Snedaker SC (1974) The ecology of mangroves. Annu Rev Ecol Syst 5:39-64

Macintyre IG, Precht WF, Aronson RB (2000) Origin of the Pelican Cays ponds, Belize. Atoll Res Bull 466-480:1-11

Mackey MD, Higgins HW, Mackey DJ, Wright SW (1997) CHEMTAX user's manual: a program for estimating class abundances from chemical markers-application to HPLC measurements of phytoplankton pigments. Rep CSIRO Mar Lab 229:1-41

Niogi KK (1999) Photoprotection revisited: genetic and molecular approaches. Annu Rev Plant Physiol Plant Mol Biol 50:333-359

Örnólfsdóttir EJ, Pinckney JL, Tester PA (2003) Quantification of the relative abundance of the toxic dinoflagellate, Karenia brevis (Dinophyta), using unique photopigments. J Phycol 39:449-457

Reed RH (1983) Measurement and osmotic significance of bdimethylsulfoniopropionate in marine macroalgae. Mar Biol Lett 4:173-181

Stefels J, van Leeuwe MA (1998) Effects of iron and light stress on the biochemical composition of antarctic Phaeocystis sp. (Prymnesiophyceae). I. Intracellular DMSP concentrations. J Phycol 34:486-495

Steinke M, Wolfe GV, Kirst GO (1998) Partial characterization of demethylsulfoniopropionate (DMSP) lyase isoenzymes in 6 strains of Emiliania huxleyi. Mar Ecol Prog Ser 175: 215-225

Sunda W, Kieber DJ, Kiene RP, Huntsman S (2002) An antioxidant function for DMSP and DMS in marine algae. Nature 418:317-320

Throndsen J (1978) Preservation and storage. In: Sournia A (ed) Phytoplankton manual. UNESCO, Paris, p 69-74

Townsend DW, Keller MD (1996) Dimethylsulfide (DMS) and dimethylsulfoniopropionate (DMSP) in relation to phytoplankton in the Gulf of Maine. Mar Ecol Prog Ser 137: 229-241

Vairavamurthy A, Andreae MO, Iversen RL (1985) Biosynthesis of dimethyl sulfide and dimethyl propiothetin by Hymenomonas carterae in relation to sulfur source and 
salinity variations. Limnol Oceanogr 30:59-70

Vernet M, Neori A, Haxo FT (1989) Spectral properties and photosynthetic action in red-tide populations of Prorocentrum micans and Gonyaulax polyedra. Mar Biol 103: 365-371

Villareal TA (1995) Abundance and photosynthetic characteristics of Trichodesmium spp. along the Atlantic Barrier

Editorial responsibility: Otto Kinne (Editor-in-Chief), Oldendorf/Luhe, Germany
Reef at Carrie Bow Cay, Belize. Mar Ecol 16:259-271

Vogt C, Rabenstein A, Rethmeier J, Fischer U (1998) Alkalilabile precursors of dimethyl sulfide in marine benthic cyanobacteria. Arch Microbiol 169:263-266

Wolfe GV, Steinke M, Kirst GO (1997) Grazing activated chemical defense in a unicellular marine alga. Nature 387:894-897

Submitted: June 22, 2004; Accepted: October 12, 2004

Proofs received from author(s): February 7, 2005 